\title{
Isolation, Identification and Screening of Antimicrobial Properties of the Marine-Derived Endophytic Fungi from Marine Brown Seaweed
}

\author{
CHANGI WONG ${ }^{*}$, PETER PROKSCH${ }^{2}$, LEE TUNG TAN $^{1}$, SAMUEL LIHAN $^{3}$, \\ AAZANI MUJAHID ${ }^{3}$, AND MORITZ MÜLLER ${ }^{1}$ \\ ${ }^{\prime}$ Faculty of Engineering, Computing and Science, Swinburne University of Technology Sarawak, \\ Kuching 93350, Malaysia; \\ ${ }^{2}$ Institut für Pharmazeutische Biologie und Biotechnologie, Universitätstraße 1, \\ Düsseldorf 40225, Germany; \\ ${ }^{3}$ Faculty of Resource Science and Technology, Universiti Malaysia Sarawak, \\ Kota Samarahan 93400, Sarawak, Malaysia
}

\begin{abstract}
Marine seaweeds are known to produce valuable medicinal compounds such as antioxidants and anticoagulants, and have been reported to display antimicrobial activity against gram positive and gram negative bacteria. Several studies have identified so-called endophytic fungi living inside their hosts as the source of active compounds. In this study marine brown seaweed, Padina sp., was studied with regards to their endophytic fungi to assess if they are the source of the reported antimicrobial activity. Twenty fungal isolates were isolated from Padina sp. collected off Talang-Talang Island, Sarawak, Malaysia. All isolates were screened for their antimicrobial properties and 11 out of 20 isolates displayed positive results. DNA was successfully extracted for five isolates and sequence analysis grouped all of them with other endophytic fungi. "Fungus 2" seems to be related to a so far uncultured endophytic fungus. "Fungus 19" showed the most promising antimicrobial properties and was chosen for further agar well assay and cytotoxicity testing. Its ethyl-acetate extract showed positive results in the agar well assay and also a cytotoxic effect on Artemia nauplii. The extract was screened using HPLC and showed a compound similar to a known anti-cancer compound, dihydromyricetin, which is also an anti-intoxicant, anti-inflammatory and anti-oxidative agent which may be responsible for the observed antimicrobial activity.
\end{abstract}

Key words: antimicrobial properties, endophytic fungi, Marine Brown Seaweed, Padina sp.

Rumput laut laut yang dikenal menghasilkan senyawa obat berharga seperti antioksidan dan antikoagulan, dan telah dilaporkan mempunyai aktivitas antimikroba terhadap bakteri gram positif dan gram negatif. Beberapa studi telah melaporkan bahwa jamur endofit yang hidup di dalam rumput laut sebagai inang adalah sumber senyawa aktif. Tujuan penelitian ini adalah mengevaluasi, apakah rumput laut coklat Padina sp. dengan jamur endofitnya merupakan sumber dari aktivitas anti mikroba yang dilaporkan tersebut. Dua puluh isolat jamur diisolasi dari Padina sp. dikumpulkan dari Pulau Talang-talang, Sarawak, Malaysia. Hasil skrining anti mikroba menunjukkan, bahwa 11 dari 20 isolat menunjukkan hasil positif. Genom DNA dari lima isolat berhasil diekstraksi dan dianalisa deret ITSnya dan dianalisa dengan kelompok jamur endofit lainnya. "Jamur 2" diduga terkait dengan jamur endofit yang tidak dapat dikultur (unculturable). "Jamur 19" menunjukkan sifat antimikroba yang paling menjanjikan dan terpilih untuk agar well assay baik dan pengujian sitotoksisitas lebih lanjut. Ekstrak etil asetat dari islat ini menunjukkan hasil positif dalam agar well assay dan sitotoksiksitas terhadap Artemia nauplii. Hasil skrining ekstrak tersebut dengan menggunakan HPLC menunjukkan senyawa yang mirip dengan senyawa anti kanker, dihydromyricetin, yang juga merupakan anti-intoxicant, anti inflamasi, dan juga agen anti oksidan yang mungkin berkaitan dengan aktivitas anti mikroba.

Kata kunci: anti mikroba, jamur endofit, rumput laut coklat, Padina sp.

Endophytic fungi have attracted the interest of scientist and pharmaceutical companies, especially since the discovery of the world's first billion-dollar anticancer drug, paclitexel (Taxol) from Pestalotiopsis microspora, which is an endophytic fungus living within the Himalayan yew tree, Taxus wallichiana (Maheswari 2006). Endophytic fungi spend their entire

*Corresponding author; Phone: +60-168716911; Email: cgwong@swinburne.edu.my life cycle within their host plant tissue without showing any apparent symptom (Strobel et al. 1998). They live symbiotically with the host plants, which provide them profuse nutriment and restful habitation for the survival (Firakova et al. 2007), while they protect their host plants from external biotic and abiotic stresses (Rodriguez et al. 2009). For instance, the endophytic fungi, Curvularia protuberate can be found on all of the non-embryonic tissues of the geothermal plant Dichanthelium lanuginosum. Neither the fungus nor 